\title{
Showcase preview
}

Please send trade news information and illustrations to Joanna Lyall at the BDJ,

Nature Publishing Group, The Macmillan

Building, 4-6 Crinan Street, London N1 9XW.

Trade news is provided as a service to readers using text and images from the manufacturer, supplier or distributor and does not imply endorsement by the BDJ. Normal and prudent research should be exercised before purchase or use of any product mentioned.

\section{CPD AT EXHIBITION}

This year's British Dental Trade Association Dental Showcase takes place at ExCel, London on October 2-4. You can register for your free ticket online at www.dentalshowcase.com or by telephoning 01494 729959. Free registration closes on 26 September. Opening times are 11-6 on October 2, 10-6 on October 3 and 10-5 on October 4 . Entrance on the day is $£ 10$.

Time spent at the exhibition qualifies as CPD and the BDTA will issue certificates of attendance. You will need to provide your GDC number when you register. Complimentary seminars on disinfection and decontamination, medical emergencies and radiography and radiation, which meet the requirements for verifiable $\mathrm{CPD}$, will be held during the three days of the exhibition.

Visitors will also have a chance to win a trip to a cooking school in Italy and each day 100 Mooley the cow soft toys will be given away to entrants who correctly note the number of stands displaying the toy.

Reader response number 50

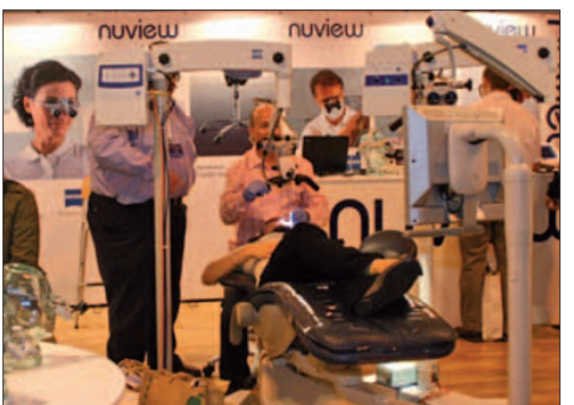

and posture requirements. All the popular Carl Zeiss products will be available to try.

Reader response number 51

\section{SEE THE LATEST IN DATA HOSTING}

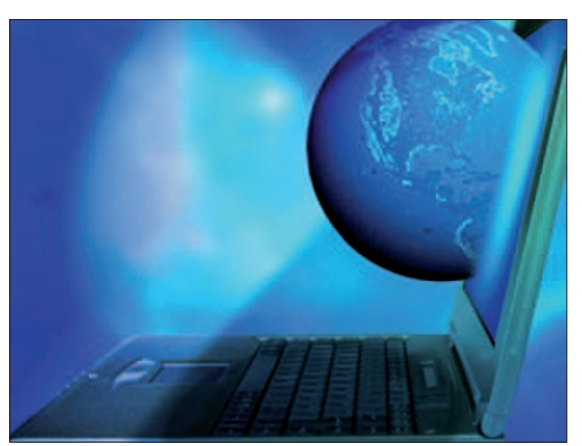

Make sure you visit the PracticeWorks team at stand H06 to see the latest innovation in practice management software and digital imaging systems. Version 3 of the Kodak R4 practice management software now has a web version which includes data hosting.

Data hosting means that the application and the data are accessed via the internet - there is no need for servers or software. R4 version 3 links directly to a credit card pin reader, directing everything to the R4 accounting system, logging each payment with a system designed specifically for dental practices. Your patients will also be able to make appointments online. They just access the online appointment book, select their preferred date, and choose from available appointment slots. Reader response number 52

\section{COMPLETE RE-FITS}

Clark Dental offers a one stop shop for refitting your surgery. Using CAD-enabled laptops and 3-D designs, experts will work with you to achieve the best solution as well as providing extensive after sales support. Clark Dental offers high quality technology from

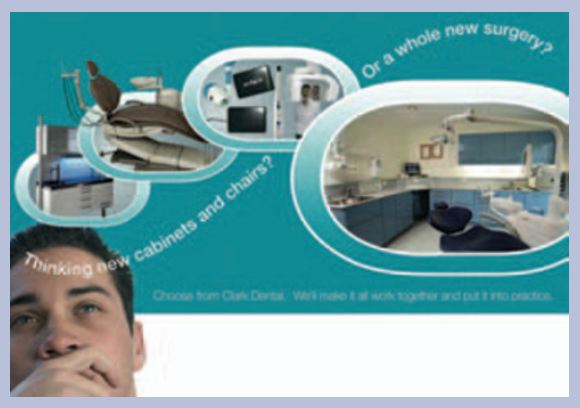

leading manufacturers, including the CDR wireless, the cable-free intraoral sensor from Schick Technologies, and Nomad, a portable hand-held cordless X-ray with rechargeable battery packs. With this expertise you can look forward to quickly creating your dream surgery.

Reader response number 53 


\section{SYNCHRONISED SERVICES}

Establish a practice which reflects your personal vision with the minimum disruption - visit the Genus group on stand G05.

Genus provides flexible and reliable design, construction and refurbishment services. The specialist team will handle every aspect of a project, from plumbing and ventilation to data, electrics and lead lining, all carefully synchronised by experienced site managers. Site assessment and move management are also part of the service. All the client needs to do is choose the equipment. Clients receive impartial advice on bespoke fixtures and signature pieces. Your plans will be completed within the agreed budget and timeframe.

Reader response number 54

to include a rapid cycle benchtop model offering handpiece irrigation.

Reader response number 55

You can be confident you hold all th aces when you invest in Eschmann's decontamination equipment. The company has more than 50 years experience and offers dentists reliability, performance and after-sales care. Visit stand J09 to see the complete in-surgery decontamination solution.

Since its launch two years ago the Little Sister autoclave has established itself as the best in the market, offering self-checking cycle verification. The autoclave continually checks every cycle and any deviations from the pre-set parameters result in the interruption of the suspect cycle.

Eschmann has also expanded its instrument washer-disinfector range

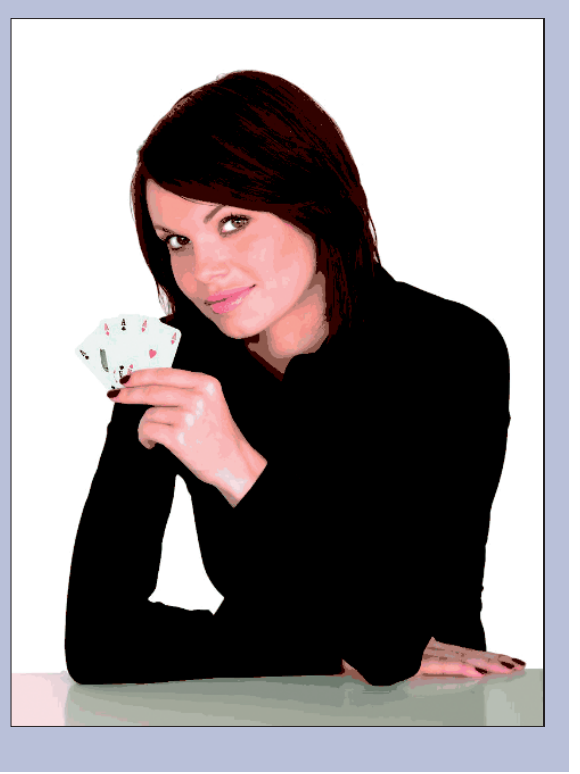

restorations. DentalAir is the only specialist company that offers a turnkey service providing clean, dry, infectionfree compressed air to dental practices, NHS clinics and PCTs nationwide. It supplies the latest oil-free compressors, pipework and ancillaries, supported by the appropriate certification and maintenance contracts. Visit us at stand T18.

Reader response number 56

\section{CHAMPAGNE OFFER}

The Dentsply team will be carrying out demonstrations and sharing knowledge of their products on stands P09, P10 and N10. They will also be handing out bottles of Veuve Cliquot champagne for orders placed during the show.

All the favourite products will be on show including the Illumine whitening system, Chemfil Molar Caps, Xeno V, Aquasil Ultra, DuoMix, and the Endo and Artio ranges.

Reader response number 57

\section{FREE CONSULTATIONS}

Sign up with Frank Taylor and Associates at stand L12 and you will be entitled to two hours free consulting worth $£ 395$. Experienced consultants will work with you to define a realistic fee income and how best to achieve this target. You will be helped motivate your team and refine your business processes. Take this opportunity to achieve a new level of prosperity.

Reader response number 58

\section{BRITISH ACADEMY OF COSMETIC DENTISTRY}

Visit the BACD's stand E01 to hear about the benefits of joining from members. Delegates will be able to hear about the training opportunities, networking possibilities, patient referral service, conferences and discounts on courses and products which are all on offer. The stand will also have details on BACD's annual conference which will be held in Birmingham on November 13-15.

Reader response number 59

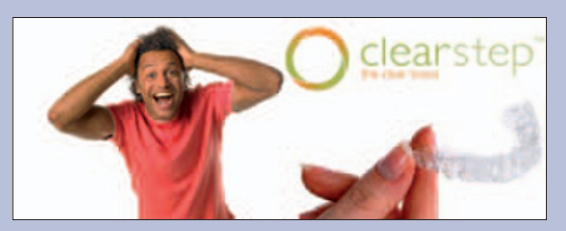

alignment and finishing and detailing. Reader response number 60 


\section{TAKE YOUR CAREER TO THE NEXT LEVEL}

Do you want to learn from high calibre staff in state of the art facilities? The Eastman has more than 50 years' experience of education and train-

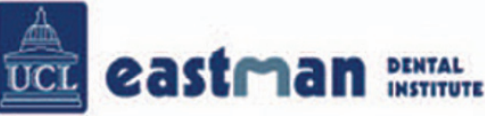

ing. Visit stand F06 and discover what is on offer for dentists and dental care professionals.

The Eastman offers on-site and distance learning CPD opportunities and full- and part-time masters programmes. Staff are particularly keen to welcome dental nurses, therapists and technicians at this year's Showcase.

Reader response number 61

\section{LEARN HOW TO MAKE A LASTING FIRST IMPRESSION}

Admor will help your practice make a truly memorable first impression. Visit stand D15 to discover how to renovate reception areas and waiting rooms with stylish furniture, signage and stationery. Learn how you can make the best use of space with the Espacio seating ranges and ask about the Nadir Chrome and Samba seating options. Go for maximum visitor comfort with the Easi-Chair or Elegance Seating, which have combinable elements to maximise space.

You can also find out about promoting your unique brand with an extensive range of promotional leaflets, business, reminder and appointment cards. Achieve your vision by selecting and coordinating products from our directory.

Reader response number 62

\section{HEALTHY WHITENING}

Beverly Hills Formula premium brand whitening products have unique combinations of antibacterial agents, low abrasion and anti-stain polishers to protect and whiten teeth. They gently remove stains from teeth without harsh abrasives.

As part of its bid to prevent gum disease by controlling the amount of plaque that builds up, Beverly Hills Formula

\section{DIFFERENT WAY OF WORKING}

Integrated Dental Holdings (IDH) owns more than 200 practices in the UK employing more than 850 dentists and providing services for more than 1 million patients. Visit stand D10 to discover how the company is becoming one of the largest owners of den- has developed a gum strengthening toothpaste. Regular brushing with this will help nourish and strengthen gums, fight plaque, remineralise and harden tooth enamel and leave breathe smelling fresher. It helps prevent bleeding gums and promote healthy growth of gum tissue. Teeth appear whiter, feel smoother and remain clearer.

For further information visit stand F14. Reader response number 63

tal practices in the UK and what it can offer in terms of career opportunities.

IDH is committed to the successful development of all its practices and the provision of excellent clinical care. It operates specialist referral clinics as well as NHS and private dental care practices.

Reader response number 64

\section{integrated dental holdings}

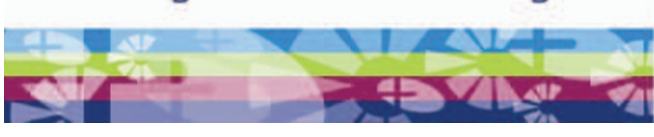

PRACTICE. MADE PERFECT.

\section{HIGH QUALITY SOLUTIONS} TO SUPPLY NEEDS

Blackwell Supplies is a market leader in the provision of cost-effective solutions for the needs of the 21st century dental clinician. Its portfolio includes Ledermix Combination Kits - a potent dental paste which is indispensable when treating patients with irreversible pulpitis who require emergency treatment.

Chlorhexidine gluconate is a germicidal mouthwash which reduces oral bacteria and fights gum disease and plaque. It is now available in aniseed and peppermint flavours. Dentomycin, a high performance solution to dental disease, Denshield Home Therapy System for sensitive teeth and Hogies MiniScope Loupes, for eye protection, are some of the other highly effective products in this portfolio.

Reader response number 65

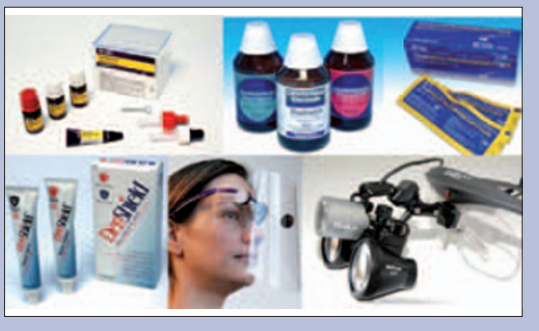

\section{BE IN COMPLETE CONTROL}

Software of Excellence's innovative EXACT system is just what is needed to give you complete control of your business. Several new features will be on display at this year's Showcase. The management of units of dental activity (UDAs) is a pressing concern for NHS and mixed practices. SOE's new UDA Manager enables you to take control of your UDAs easily and effectively on one user-friendly system.

Also on display will be the new Presentation Manager and Recall Manager features which will help you create estimates and retain patients. The new Computer Telephony Integration takes practice efficiency to a new level. As soon as a patient telephones the practice their details appear on screen, with all relevant information.

Reader response number 66 


\section{ENHANCING PATIENT SMILES}

Come to the DMDS stand N04 to see the new QuickLase dual soft tissue management system at work. It is the smallest, most affordable soft tissue tactile diode laser on the market. This equipment replaces electrosurgery and for the hygienist, gum management procedures can be carried out quickly and easily.

\section{INNOVATIVE PRODUCTS}

Kerr will have two new products on display at Showcase. The extended Herculite family now includes the aesthetic anterior and posterior Herculite XRV Ultra with nano-technology.

New Maxcem Elite with improved bond strength takes cementation to the next level of simplicity. A self-etch, self-adhesive resin cement, it is perfect for all indirect restorations.

You will also be able to take a look the Pinnacle range of barrier products: Seal-Tight disposable syringe tips that will save you thousands of pounds.

The unique WIS Smile Enhancement System is a fast and effective bleaching system, combining both power and soft bleaching. Your patients will experience less sensitivity and you will have one simple, portable unit. This could help revolutionise your practice. Reader response number 67
Dealing direct with the manufacturer

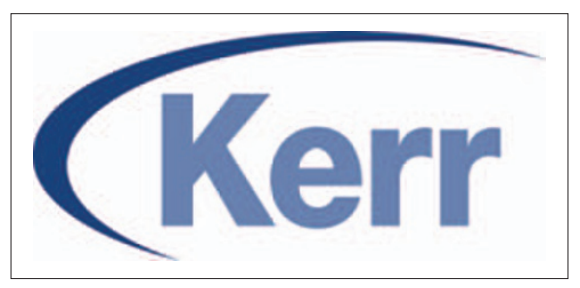

provide complete separation of the air and water supply; Periostar for sharpening periodontic instruments; and Cleanic prophylaxis paste and Cleanicdent toothpaste. Visit stand P07 for more information.

Reader response number 68

\section{ELITE PRODUCTS}

Zhermack will be displaying several new products on its stand F07. Elite Glass is a medium body transparent silicone. This is used as an impression matrix to make temporary composite veneers which can then be light-cured in the mouth.

Hydrorise is a new A-Silicone with enhanced hydrophilic properties. ModulMix is a universal A-silicone mixing machine. Occulfast CAD is a scannable bite registration silicone for CAD CAM scanners. A new autoclave Zetaclave and Alghamix, a bubble-free alginate mixing machine will also be on show.

Reader response number 71

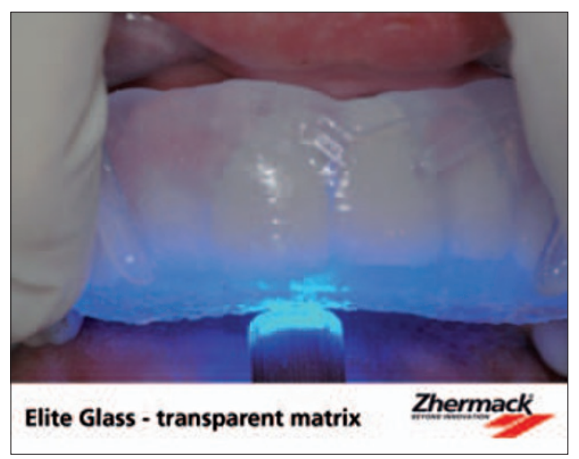

and education support, the DLA also lobbies government and liaises with other dental organisations to protect the interests of members. Its comprehensive portfolio of services will be explained at Showcase - visit stand C15.

Reader response number 69

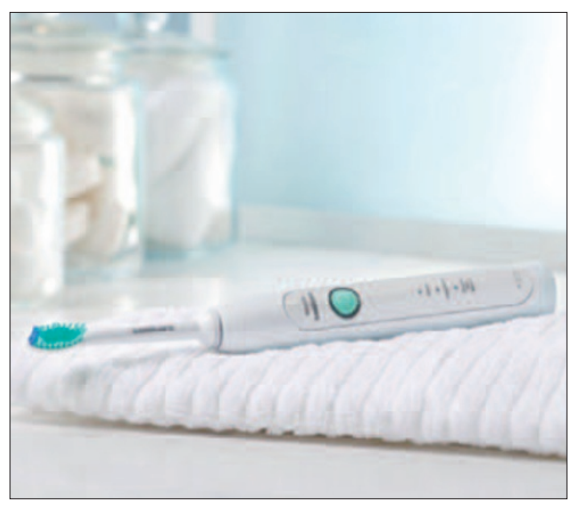

booth and will be able to take the brush head away with you.

You may even beat last year's record when 6,000 delegates queued to try the FlexCare brush.

Reader response number 70

\section{SEEING IS BELIEVING}

Make sure you are aware of Evident's excellent, affordable dental imaging products by coming to stand K02. Here you will find the Orascoptic loupe to suit everybody, whether you are looking for fashion or functionality. The new HiRes Elliptical Classs III loupes have been added to the stylish Victory designer frames. Try one with our new Zeon Apollo LED light system, the smallest most lightweight headlamp available. It guarantees a bright white light, perfect for a full day's work. Evident's team of consultants will be on hand to provide technical information and advice.

Reader response number 72

Fvident expanding horizons see for yourself the ference after only two minutes. You can do this in a private brushing 


\section{COMBINE EFFICIENCY WITH AESTHETICS}

The comfort of all staff is a key issue in running a successful practice. KaVo's aim is always to supply products that are ergonomically designed to improve the aesthetics and efficiency of your working environment.

A variety of dental units and a choice of delivery systems are offered to suit all needs and budgets, including the economical Primus 1058 unit and the COMPACTchair with knee break. The comprehensive range of top quality handpieces will be demonstrated. Come to stand H05 and you will also be able to see the i-CAT Cone Beam Scanner and find out how it will improve your practice.

Reader response number 73

\section{DURABLE HANDPIECES}

Make sure you have first hand experience of NSK's durable handpieces on stand J03 at this year's Showcase.

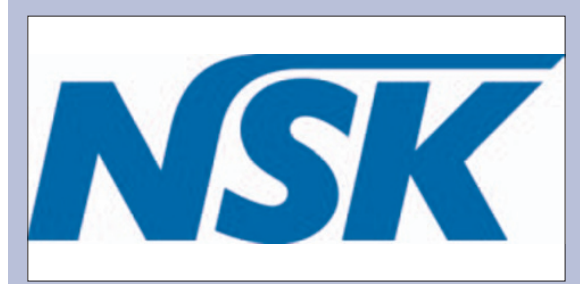

Pick up a turbine or contra-angle from the new TiMax $\mathrm{X}$ series and feel for yourself how the sleek lines of solid titanium body can make daily clinical procedures much more comfortable. We are confident the whole dental will be impressed by the ever increasing portfolio. We can meet you demands in restorative procedures, prosthetics, endodontics, orthodontics and surgical procedures.

Reader response number 74

\section{LOUPES OFFER FOR DENTAL STUDENTS FROM BDA}

Final year dental students will be offered a finance deal from the British Dental Association to buy dental loupes. Students are also to be offered free membership of the BDA for their final year of study. The new benefit will be launched at the BDA's stand S05.

Peter Ward, BDA chief executive, said 'Dental loupes are an important

\section{ITALIAN CRAFTSMANSHIP}

Castellini will be displaying its impressive range of dental chairs on stand M07. Make sure you pay a visit for a demonstration of the Logos and Duo. The Duo's innovative features include: ambidextrous operation, an accessible piece of equipment for dentists providing magnification to make treatment easier and improving posture. We want to encourage young dentists into good habits right from the start of their career. We're delighted DP Medical Systems and Nuview are supporting the initiative.'

Reader response number 75

and user-friendly console and functional instruments with tension free levers. Trained representatives will be on hand to show the performance and durability of these products. See what we offer in terms of aesthetic design and efficient function.

Reader response number 76

\section{ENSURE FINANCIAL SUCCESS}

Sourcing competitive finance may not be easy at the moment but you can benefit from help from the Medifinance team who will be available on stand G06. With decades of experience Medifinance will ensure you get the best possible advice.
Dentists in the team will be on hand to give the benefit of their expertise. Our independent status and international contacts mean that funding can generally be found and confirmed quickly. Our products include finance for equipment and vehicles, loans for tax payments, partnership

\section{DIGITAL RADIOGRAPHY}

Whether you are upgrading or replacing your digital radiography equipment, be sure to visit stand G09 where the Vatech and E-Woo range of products will be on display.

They are both competitively priced and technically advanced. The upgradeable PaX-Uni3D series and the Picasso CT series are among those that will be on show. Ask about trade-in allowances on your existing panoral systems.

Reader response number 77

\section{SHARPEN YOUR MARKETING}

Designer Dental, an experienced promotion and marketing company will be meeting delegates on the Frank Taylor (L11) stand.

Visitors will have the opportunity to discuss their marketing needs and how to tailor their plans to patients' needs. Learn how to maximise client spend and achieve your objectives.

\section{Reader response number 78}

\section{WIN A CRUISE TO BRUGES}

Essential Money will be running a prize draw at Showcase for a twonight cruise to Bruges with a £50 on board credit. The draw is being organised in association with Premier Cruise Club and PEO Cruises.

Essential Money helps dentists at all stages of their careers. This specialist independent financial adviser can negotiate rates with lenders and advise on legislative changes.

Enliven your time at Showcase with the possibility of a free holiday.

Reader response number 79 